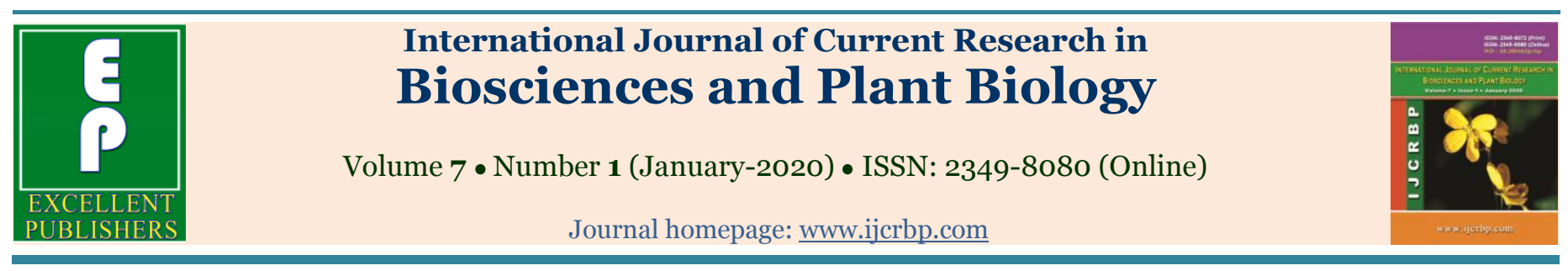

Original Research Article

doi: $\underline{\text { https://doi.org/10.20546/ijcrbp.2020.701.002 }}$

\title{
Identification of wild macrofungi from Southern West of Saudi Arabia
}

\author{
D. A. El-Wakil1,2* and A. N. Al-Gifri ${ }^{1,3}$ \\ ${ }^{1}$ Department of Biology, College of Science, Jazan University, Saudi Arabia \\ 2Plant Pathology Research Institute, Agricultural Research Centre, Egypt \\ 3Department of Biology, College of Science, Aden University, Yemen \\ ${ }^{*}$ Corresponding author; e-mail: de107@yahoo.com
}

\begin{tabular}{|c|c|}
\hline Article Info & ABSTRACT \\
\hline $\begin{array}{l}\text { Date of Publication: } \\
\text { o6 January } 2020\end{array}$ & \multirow{3}{*}{$\begin{array}{l}\text { Macro-fungi (Mushrooms) considered a great potential natural bio-resource of } \\
\text { basidiomycetes; also, source of proteins and vitamins for human. In the present study } \\
\text { twelve mushrooms were identified and one of Terfezia sp. The importance of } \\
\text { mushroom all over the world, give a push to many mycologists to study the wonderful } \\
\text { macro-fungi. The different ecological conditions, affects on the wild fungus especially } \\
\text { humidity and temperature degrees. The morphological characteristics as the stalk } \\
\text { height, diameter, cap size and fresh weight of mushrooms were considered as a } \\
\text { parameter for differentiation between different types. Twelve species of mushrooms } \\
\text { belonging to different genera were collected and identified from three locations in } \\
\text { Jazan governorate southern of Saudi Arabia; Harub, Al-Aridhah and Samtah, which } \\
\text { found a suitable area for this kind of macro fungi in Saudi Arabia. In addition, in Al- } \\
\text { Sahalil Jazan region the Terfizia sp. Was recorded underground with some wild plants. }\end{array}$} \\
\hline Keywords & \\
\hline $\begin{array}{l}\text { Ascomycetes } \\
\text { Basidiomycetes } \\
\text { Edible fungi } \\
\text { Fruiting bodies } \\
\text { Higher fungi } \\
\text { Mushrooms }\end{array}$ & \\
\hline
\end{tabular}

\section{Introduction}

The wonderful fungi (mushrooms) are cultivated in many countries and wild species are a good source for human food and medicinal uses. Besides its role in recycling of agricultural organic waste and plant debris, wild mushrooms are nutritious for human food. Mushrooms have been recognized recently for their important role in recycling of organic wastes (Abu El-Souod et al., 2000; Mohamed et al., 2018). Production of oyster mushroom (Pleurotus ostreatus) has received special attention in many countries all over the world due to its ease cultivation. Different aspects in mushroom production were studied (Mohamed et al., 2011 and 2014). The high contends of nutritional, bioactive compounds and antioxidants in fruiting bodies are very important materials (Mohamed and Farghaly, 2014). The fungus mushrooms has an important medication usage, as the red mushroom (Ganoderma lucidum) is cultivated strictly for its medicinal benefits. Survey of wild edible and medicinal mushrooms all over the world in the recent times was stated by the Agriculture and Food Organization (FAO). In different countries many investigators has been attracted for studying the edible and medicinal mushrooms types. A large number of wild mushroom species were identified and their amino acid composition was studied (Mdachi et al., 
2004). Different wild mushroom species was found to be a potential source of essential amino acids (Mdachi et al., 2004). Fourteen species of mushrooms belonging to nine genera from seven localities in Al-Taif Governorate of Saudi Arabia were collected and identified by Abou-Zeid and Altalhi (2006) and Gray (1997) reported that Agaricus campestris is common wild mushrooms in America and Europe. A total of 142 species of wild commercial mushrooms were identified and recorded on the wild fungus markets in Yunnan, China by Wang et al.2004.More than eight hundred macro-fungal species of 175 genera were recognized and reported from Yunnan province of southwestern China where wild edible mushrooms have become a very important income for the people in mountain forest and countryside areas (Liu, et al., 2009), and Abu El-Souod et al. (2000). reported thirteen species of mushrooms belonging to ten genera (Agrocybe, Armillaria, Coprinus, Drosella, Hebeloma, Hygrophorus, Lepiota, Leptonia, Panaeolus and Tricholoma).

Three species of wild mushrooms collected during the wintertime from Alexandria city (Egypt) and identified them as being Agaricus campestris, Agaricus rodmani and Collybia sp. by Liu et al. (2009) and Zakhary et al. (1983). The aim of the present work was to identify some of wild macro fungi of mushrooms in different locations in Jazan region in southern west of Saudi Arabia.

\section{Materials and methods}

\section{Source of wild mushroom samples}

Different genera of mushrooms were collected from three localities in Jazan Governorate during the period from September 2019 to December 2019. Localities are shown in Fig. 1. Samples were found in wet places after rain and low temperature degrees or on the decayed plants and the leaves of trees as organic natural materials. Mushroom samples were photographed and collected from their natural sites and kept for further laboratory identification and laboratory studies under $5^{\circ} \mathrm{C}$ in refrigerator .

\section{Laboratory studies}

The collected fruiting bodies were identified according to Ellis and Ellis (1990), Verma et al. (2017) and Phillips (1981). Some lab studies were made for macrofungus identification by free hand sections and microscopic examinations under $\times 25$ and $\times 40$ magnification.

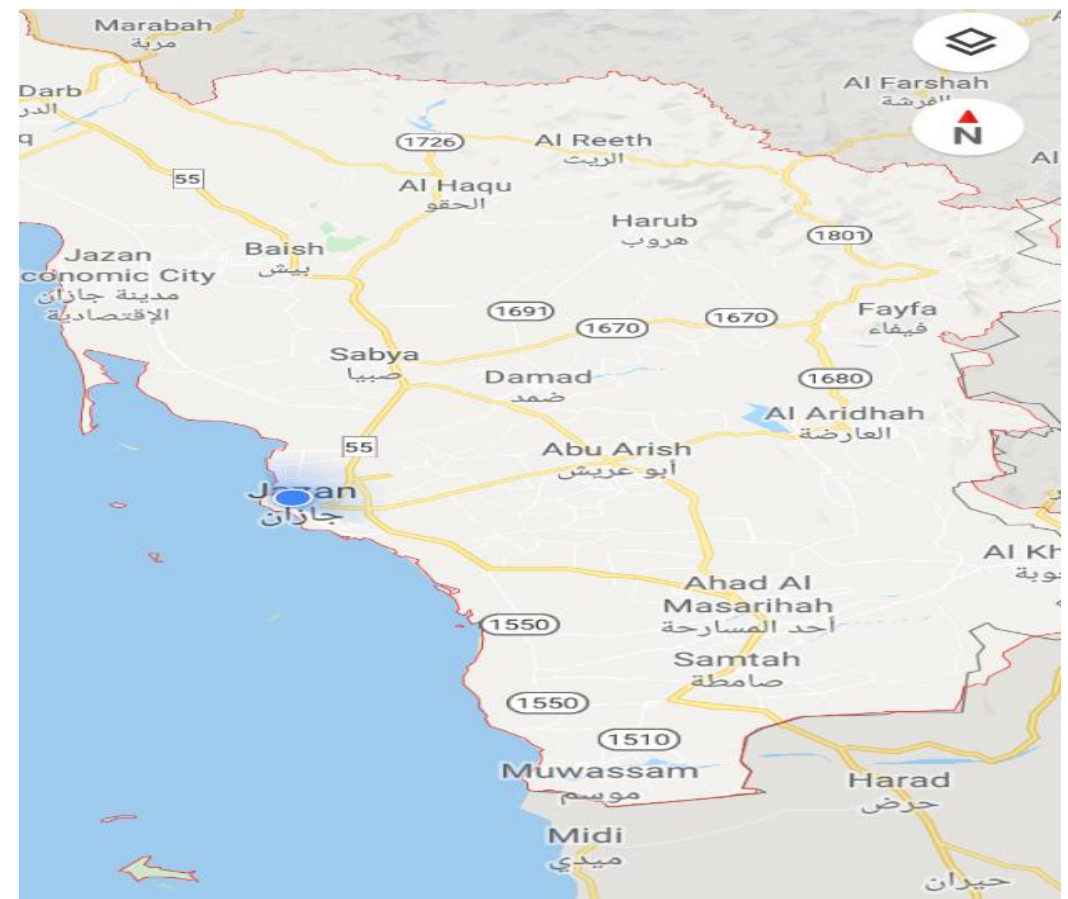

Fig. 1: Showing the location of collecting samples in Harub, Al-Aridhah and Samtah (Jazan Region) southern west of Saudi Arabia (Source: Google Maps). 


\section{Results and discussion}

\section{Mushroom types}

During the course of the present study 12 mushrooms spp. and one Terfezia sp. were collected from different regions in Jazan and identified as the following data (Fig. $2 \mathrm{~A}-\mathrm{V}$ ):

(A) Agaricus sp.: white, cap, subglobose becoming, silky, button shape, turning pinkish and eventually blackish, it is edible.

(B) Agaricus moelleri: Cap, white then rose brownish when mature, fleshy, globose or hemispherical then convex. Gills rose-white in young, then brownish in mature fungi. Stipe, white sometimes rose in young specimens.

(C) Ganoderma applanatum: Ganoderma means having a "shiny or lustrous skin"; applanatum means "flattened" and refers to the flat, shelf-like appearance (applanate) of the fungus, useful for medicinal industries.

(D) Coprinus sp.: A common fungus often seen growing on lawns, along gravel roads and waste areas. The fruit bodies first appear as white emerging from the ground, and then the bellshaped caps open out. The small gills beneath the cap are white, then pink, and finally turn black and secrete a black liquid filled with spores.

(E) Wild Ganoderma sp.: includes a genus of polypore fungi in the family Ganodermataceae that includes about 80 species, many from regions all over the world. This fungus is used for medicinal purposes.

(F) Coprinus atramentarius: Saprobic; clustered in grass, on decaying wood or on the ground from buried wood; May through September. The diminutions the Caps are $5-7.5 \mathrm{~cm}$ wide; stipes are 4-15 cm long and 1-2 cm thick. The cap is dry, gray to gray-brown; with shallow grooves on the margin (radially lined or striate). Small scales may form near the center.

(G) Podaxis pistillaris: Podaxis sp. in the open field is whitish at early stages becoming yellowish to rusty-brown in color at maturity, covered with scales when young. Pileus is ellipsoidal, $5-8 \mathrm{~cm}$ in length, 1-2 cm in diam., white becoming yellowishbrown in color. It is fragile, leathery, and woody at maturity, stipitate and pileate and odorless. Ali and El-Wakil (2015) reported Podaxis pistillaris in Jazan region for the first record.

(H) Lepiota procera: Cracked, brown. Gills whitish, hollow when mature, with brown stripes and coarse scales along its entire length. Edible.

(I) Wild Coprinus sp.: Clustered in grass, on decaying wood or on the ground from buried wood; May through September. The dimensions the Caps are 5-7.5 cm wide; stipes are 4-15 cm long and 1-2 cm thick as reported by Lehmann and Khazam (1992).

(J) Lepiota cristata: Saprobic; growing scattered or gregariously, often in disturbed ground areas like paths, ditches, lawns, and so on, but also on the forest floors under hardwoods or conifers; summer and fall; apparently widely distributed all over the world (Zamora and Neito, 1995; Alofe et al., 1996).

(K) Agaricus bisporus: Scattered on pizzas, gregarious on salads, densely clustered in grocery stores-and occasionally scattered to gregarious on manured soil, compost piles, in lawns, and so on, as a native species and as an escapee from cultivation (Gan et al., 2001; Chen et al., 2005; Rapoir, 1997).

(L) Earlier growth of Agaricus sp.: It shows the earlier face of the fungus growing stage it is scattered on pizzas, gregarious on salads, densely clustered in grocery stores and occasionally scattered to gregarious on manure soil as reported by Taylor (2010) and Benchawattananon (2016).

\section{Terfezia species}

Desert truffles are socio-economically important fungi and are being utilized in Arabian gulf countries including Saudi Arabia and several other countries of the world, for both food and medicine for many countries (El-Enshasy et al., 2013: Manzelat, 2019). Many studies showed that the desert truffle extracts have antibacterial properties against bacteria and pathogenic organisms by Richards (1997). This fungus was observed during January 2019, after rain fall in 
Harub region (Jazan) with different growing stages, and these results are similar to that reported by Sharma and Doshi (1996).

\section{Conclusion}

Wild Macro-fungi considered a great nutritious for human. Mushrooms have been recognized recently for their important role. The wonderful Macro-fungi need more and more research to cover all the wild species all over the kingdom and in other countries to study the environmental conditions, which affects on their growth and reproduction.

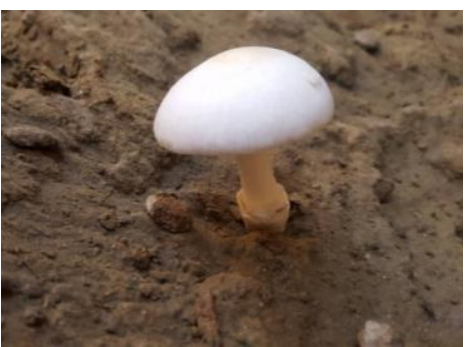

(A) Agaricus sp.

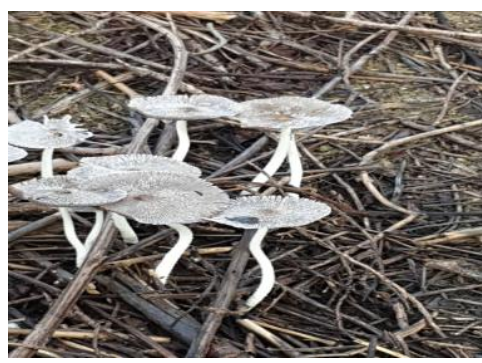

(D) Natural wild Coprinus sp.

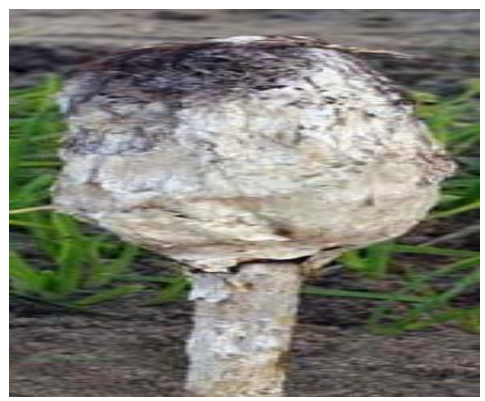

(G) Podaxis pistillaris

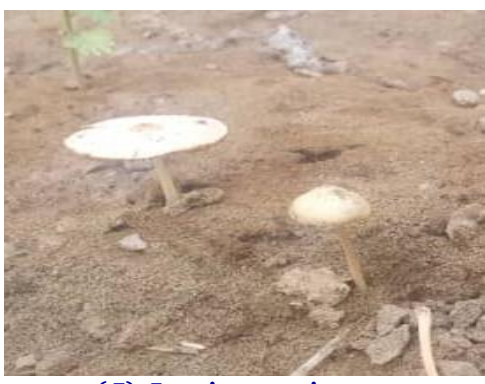

(J) Lepiota cristata

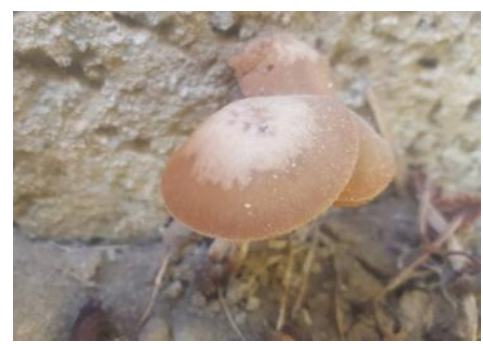

(B) Agaricus moelleri

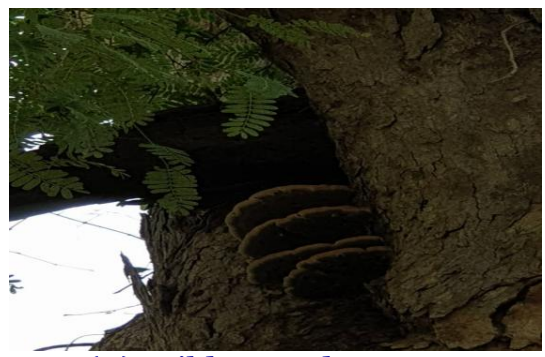

(E) Wild Ganoderma sp.

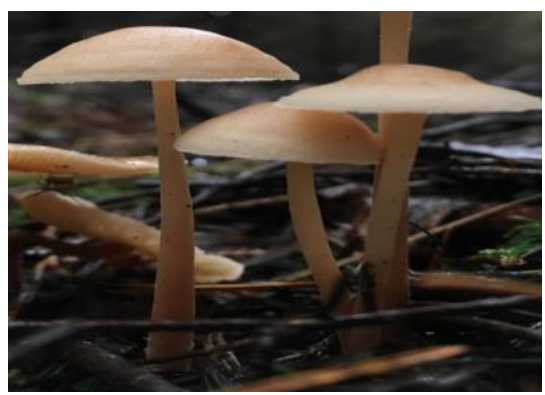

(H) Lepiota procera

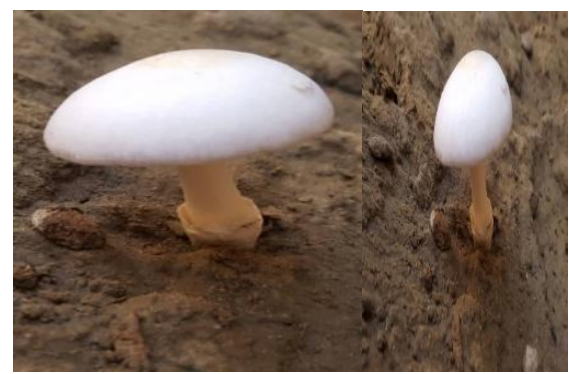

(K) Agaricus bisporus

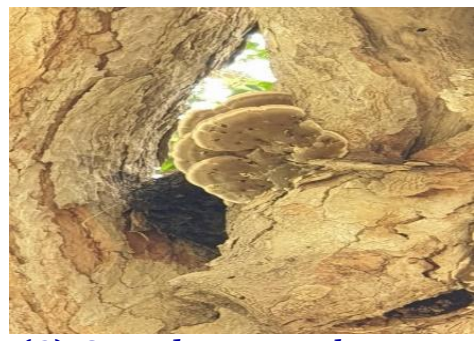

(C) Ganoderma applanatum

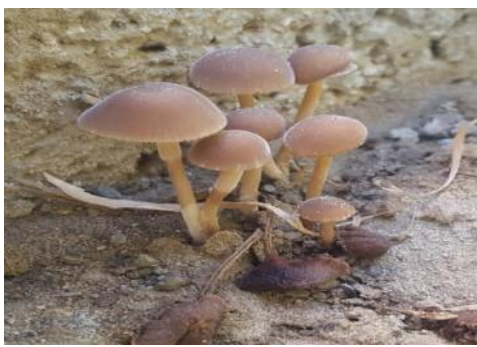

(F) Coprinus atramentarius

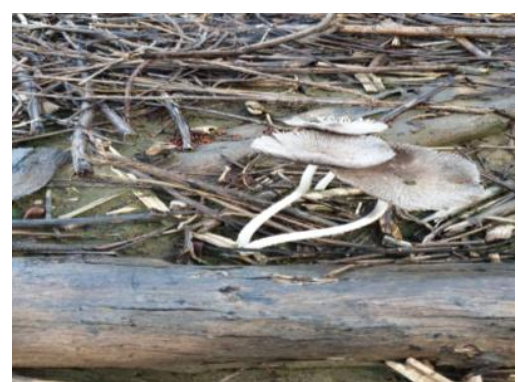

(I) Wild Coprinus sp.

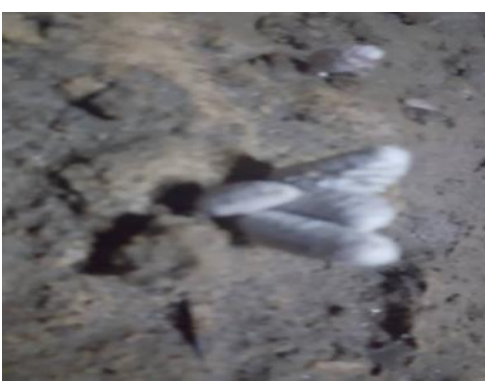

(L) Earlier growth of Agaricus sp. 


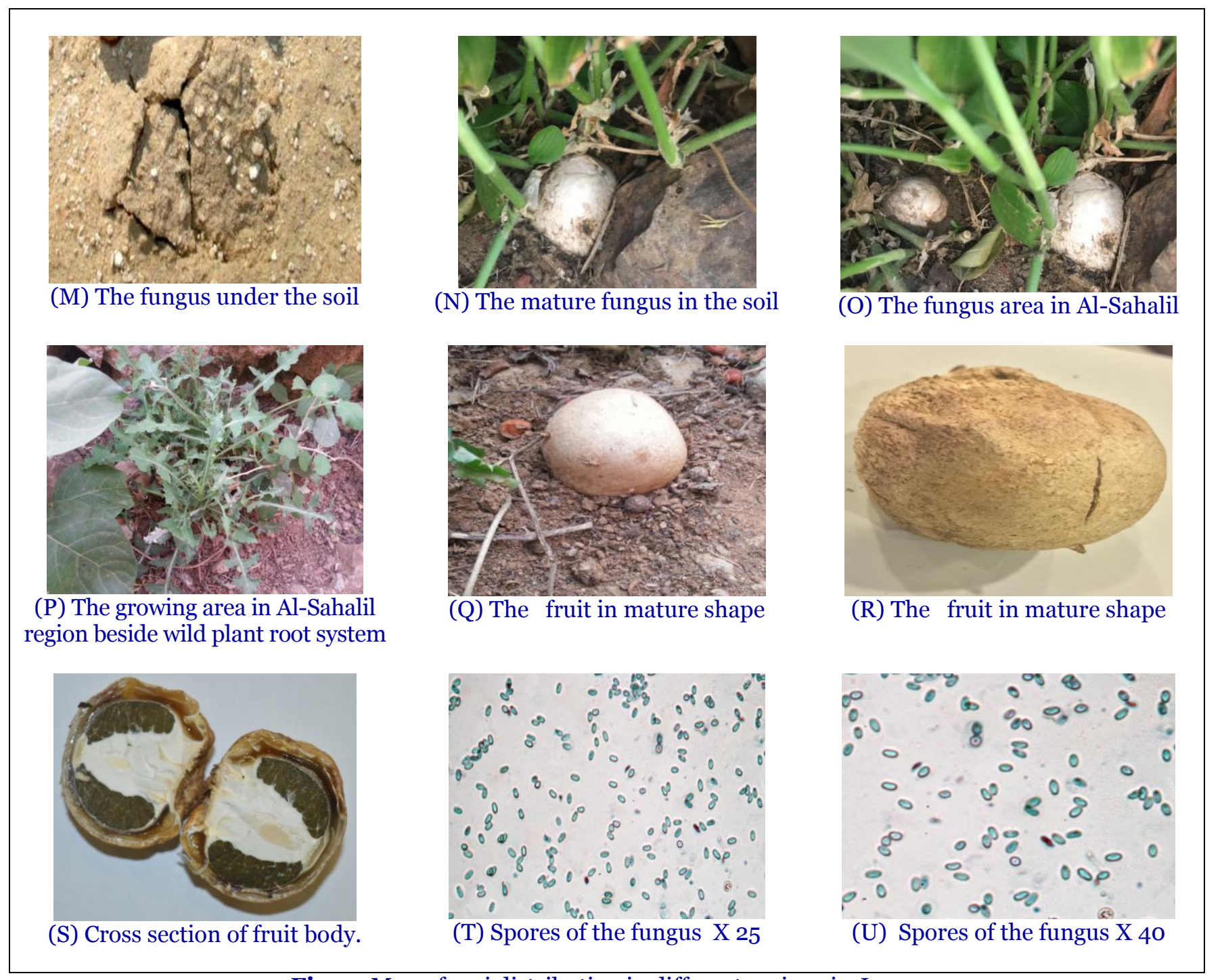

Fig. 2: Macrofungi distribution in different regions in Jazan.

\section{Conflict of interest statement}

Authors declare that they have no conflict of interest.

\section{Acknowledgement}

The authors would like to thank Dr. M. Takotatel and Dr. R. Mocikkal, College of Science, Biology Department, Jazan University for their help during this work.

\section{References}

Abu El-Souod, S. M., Assawah, S., Bedaiwy, M., 2000. Survey of mushrooms and polypores fungi in Delta region of Egypt. Proc. $1^{\text {st }}$ Int.
Conf. Biol. Sci. (ICBS), Fac. Sci. Tanta Univ. 7-8 May, 2000, 1: 525-545.

Ali, E. G., El-Wakil, D. A., 2015. First record of Podaxis pistillaris (L.EX PERS.) from Jizan region in Saudi Arabia. Int. J. Curr. Res. 7(2), 12654-12657.

Abou-Zeid, A. M., Altalhi, A. E. , 2006. Survey of some mushrooms in Al-Taif Governorate of Saudi Arabia. World J. Agric. Sci. 2(1), 1-5.

Alofe, F., O. Odeyemi and O.L. Oko, 1996. Three edible mushrooms from Nigeria: Their proximate and mineral composition. Food for Human Nutrition, 49: 63-73.

Benchawattananon, R., 2016. Biodiversity of mushrooms in conservative forest in Dansai district of Loei Province, Thailand. Trop. Life Sci. Res. 27(Suppl.1), 103-109. 
Chen Li and H.O. Nicholas, 2005. The most widely recognized mushroom: Chemistry of the genus Amanita. Life Science, 78: 532-538.

Ellis, M.B. and J.P. Ellis, 1990. Fungi without Gills (Hymenomycetes and Gasteromycetes). Chapman and Hall, London EC $4 \mathrm{P} 4 \mathrm{EE}$.

El-Enshasy, H., Elsayed, E. A., Aziz, R., Wadaan, M. A., 2013. Mushrooms and truffles: Historical biofactories for complementary medicine in Africa and in the Middle East. Evidence-Based Compl. Alt. Med. 2013, Article ID 620451, 10 pages.

Gray, W., 1997. The use of fungi as food processing. CRC Press, New York, USA.,pp: 30.

Gan, Q., B. Duanmu, L. Hong, Q. Gan, B. Duanmu and L. Hong, 2001. Study on sustainable development of edible mushroom and ecological environment. J. Zhejiang Fores. Sci. Technol., 21: 71-76.

Lehmann, P. and U. Khazam, 1992. Mushrooms poisoning by Chorophyllummclybdites in the midwest United States. Cases and review of the syndrome. Mycopathologia, 118: 3-13.

Liu Pei-Gui, Wang Xiang-hua. 2009, Fungus Kingdom: Yunnan of China and their ectomycorrhizalMacrofungal species diversity, ActaBotanicaYunnanica Suppl.14:15-20.

Mohamed F. Mohamed1, Azza A. Tawfik1 and PeiGui Liu, 2018. Identification of common edible macrofungi in wild status from Upper Egypt. The 9th Int. Conf. for Develop. and the Env. in the Arab world, April, 15-17, 2018.

Mohamed, M.F., A.G. Haridy, M.H. Aboul-Nasr and M.M., Soliman, 2011. Prolonged water soaking for sawdust substrate and adding wheat bran enhance oyster mushroom productivity. Assiut J. Agric. Sci. 42(5):66-84.

Mohamed, M. F., D. M.T. Nassef, E. A. Waly and A. M. Kotb,2014. Production of oyster mushroom (Pleurotus spp.) intercropped with field grown faba bean (Viciafaba L.) Asian J. Crop Sci. 6(1):27-37.

Mohamed, E.M. and F.A. Farghaly, 2014. Bioactive compounds of fresh and dried
PleurotusostreatusMushroom. International Journal of Biotechnology for Wellness Industries, 3:4-14.

Mdachi, S.J.M. ,M. H. H. Nkunya, V. A. Nyigo and I. T. Urasa, 2004. Amino acid composition of some Tanzanian wild mushrooms. Food Chemistry, 86(2):179-182.

Manzelat, S. M., 2019. Mushrooms in Saudi Arabia (local and imported). Int. J. Curr. Res. Biosci. Plant Biol. 6 (8), 8-12.

Philips, R., 1981. Mushrooms and other fungi of Great Britain and Europe. Pan Books / Ltd., Cavaye place, London. S.W., pp: 109.

Rapoir, S., C. Marion, Y. Pelissier and J.M. Bessiere, 1997. Volatile composition of fourteen species of fresh wild mushrooms (Boletales). J. Essential Oil Res., 9: 231-234.

Richards, R.T., 1997. What the natives know: Wild mushrooms and forest health.

J. Forest., 95: 5-10.

Sharma, Y.K. \&Doshi, A. 1996. Some studies on an edible wild fungus

Phelloriniainquinans, in Rajasthan, India. Mushroom Research, 5: 51-53.

Taylor, T., 2010. Student's Hand-book of Mushrooms of America, Edible and Poisonous. Outlook Verlag GmbH, Frankfurt.

Verma, D. and A. Chauhan, 2017. A Handbook of Mushroom Production in India. Lap Lambert Academic Publishing, 336p.

Wang Xiang-hua, Liu Pei-Gui and Yu Fu-Qiang, 2004. Color atlas of wild commercial mushrooms in Yunnan,China. Yunnan Sciences \& Technology Press 1-136.

Zakhary, J. W., M Taiseer, A. Abo-Bakr, R. ElMahdy, A. Shehata and M. El-Tabey. 1983. Chemical composition of wild mushrooms collected from Alexandria, Egypt. Food Chemistry, 11(1):31-41.

Zamora, M. and D.P. Neito, 1995. Natural production of wild edible mushrooms in the south-western rural territory of Mexico city. Mexico. Forest Ecology and Management, 72: 13-20.

\section{How to cite this article:}

El-Wakil, D. A., Al-Gifri, A. N., 2020. Identification of wild macrofungi from Southern West of Saudi Arabia. Int. J. Curr. Res. Biosci. Plant Biol. 7(1), 17-22.

doi: https://doi.org/10.20546/ijcrbp.2020.701.002 